\section{Yield of Vegetable Amaranth in Diverse Tanzanian Production Environments}

\author{
Fekadu Fufa Dinssa ${ }^{1,6}$, Peter Hanson ${ }^{2}$, Dolores R. Ledesma ${ }^{3}$, \\ Ruth Minja ${ }^{4}$, Omary Mbwambo ${ }^{1}$, Mansuet Severine Tilya ${ }^{5}$, and \\ Tsvetelina Stoilova ${ }^{1}$
}

\begin{abstract}
AdDitional index wORDs. African traditional vegetable, Amaranthus species, leaf vegetable, mega-environment, seasonality

Summary. Amaranth (Amaranthus sp.) is an important leafy vegetable in Africa where most farmers grow unimproved landraces. Information about amaranth genetic diversity and its adaptation to different environments will help breeders develop improved commercial varieties that meet market requirements. The objectives of this study were to investigate the performances of amaranth entries for vegetable yield across locations and seasons, assess the relative contributions of genetic vs. environmental sources of variation to yield, and cluster locations into mega-environments (MEs) to suggest future test sites. Twenty-six diverse entries were evaluated for vegetable yields in replicated trials at five locations in wet-cool and hot-dry seasons in Tanzania. Season explained the highest proportion $(52.1 \%)$ of the total sum of squares followed by entries (24.9\%) and locations $(23.0 \%)$. Mean yield across the hot-dry season trials $\left(27.7 \mathrm{t} \cdot \mathrm{ha}^{-1}\right)$ was $47.3 \%$ greater than the mean yield across wet-cool season trials $\left(18.8 \mathrm{t} \cdot \mathrm{ha}^{-1}\right)$. Differences among entries in vegetable yield were higher in the hot-dry season than in the wet-cool season, indicating that gain from selection is likely to be greater in the hot-dry season. Most entries performed well in either wet-cool or hot-dry season but a few entries were adapted to both seasons. Two MEs were identified, one characterized by lower altitudes, higher temperatures, and less fertile soils, and a second ME associated with higher altitudes, lower temperatures, and more fertile soils. Each ME may serve as an initial selection site for their respective target environment. Targeting a specific season may give a better chance of finding high-yielding varieties.
\end{abstract}

A maranth, known by various local names such as "Mchicha" in Tanzania, "Terere" in Kenya, "Aluma" and "Heberxefa" in Ethiopia, and "Ddodo" in Uganda and Rwanda, is a popular traditional African leafy vegetable with a long cultural tradition in East Africa and other regions on the continent. The leaves are rich in essential vitamins (provitamins A, C) and minerals such as iron, zinc, and calcium (Kamga et al., 2013; Mburu et al., 2012; Schonfeldt and Pretorius, 2011; Yang et al., 2013) that are deficient in the local diets.

The amaranth family (Amaranthaceae) includes $\approx 60$ species (Caselato-Sousa and Amaya-Farf'an, 2012). The names of at least nine species cultivated or harvested in the wild in Africa are as follows: purple/ red amaranth or bush greens (Amaranthus cruentus), spleen amaranth (Amaranthus dubius), Chinese spinach (Amaranthus tricolor), slender or livid amaranth (Amaranthus blitum), and Thunberg's pigweed (Amaranthus thunbergii) (Grubben, 2004a, 2004b, 2004c, 2004d, 2004e); prince's feather (Amaranthus bypochondriacus), spiny amaranth or thorny pigweed (Amaranthus spinosus), and green amaranth or pigweed (Amaranthus viridis) (Jansen, 2004a, 2004b, 2004c); and Mediterranean amaranth (Amaranthus graecizans) (Maundu and Grubben, 2004). The common names, widely recognized ones, were taken from Ebert et al. (2011). Species distribution in Africa is not clear because of confusion over small morphological differences among the various related species (Jansen, 2004a). Amaranth species have a $\mathrm{C}_{4}$ photosynthetic pathway and perform well at high temperatures compared with $\mathrm{C}_{3}$ plants (Stallknecht and Schulz-Schaeffer, 1993). Most species are annuals and grow to heights of 125 to $200 \mathrm{~cm}$, and produce spike, spike-like, or paniculate inflorescences with unisexual flowers. Interspecific and intraspecific variation exists for various traits, such as early growth vigor or early biomass accumulation, earliness to flowering, leaf shape and size, plant height, stem thickness, branching habit, and panicle shape, size, and color that may help them adapt to diverse environmental conditions (Grubben, 2004a, 2004b; Jansen, 2004a, 2004b, 2004c).

$A$. cruentus, $A$. dubius, and $A$. bypochondriacus are the most widely grown species in Tanzania and other countries in Africa (Grubben, 2004a, 2004b; Jansen, 2004a). A. cruentus and $A$. dubius grow from sea level to 2000-m elevation (Grubben, 2004a, 2004b), A. hypochondriacus grows from sea level to at least $1000-\mathrm{m}$ elevation (Jansen, 2004a), and $A$. tricolor grows up to $500-\mathrm{m}$ elevation (Grubben, 2004c). In Africa, $A$. cruentus and $A$. bypochondriacus are mainly grown as fresh vegetables, although the grain is consumed to a lesser extent. A. bypochondriacus grows quickly and is amenable to a single harvest or uproot harvesting, and is well-adapted to short crop seasons and resource-limited environments. A. dubius, cultivated and grown in the wild, is recognized for its dark green leaves, branching habit, slow early growth, and a tendency for late flowering that prolongs vegetative growth and allows multiple leaf harvests (Grubben, 2004b).

Demand for amaranth and other traditional African vegetables by city populations is rapidly increasing (Chelang'a et al., 2013), prompting

\begin{tabular}{llll}
\hline $\begin{array}{l}\text { Units } \\
\begin{array}{l}\text { To convert U.S. to SI, } \\
\text { multiply by }\end{array}\end{array}$ & U.S. unit & SI unit & $\begin{array}{l}\text { To convert SI to U.S., } \\
\text { multiply by }\end{array}$ \\
\hline 0.3048 & $\mathrm{ft}$ & $\mathrm{m}$ & 3.2808 \\
2.54 & inch(es) & $\mathrm{cm}$ & 0.3937 \\
25.4 & inch $(\mathrm{es})$ & $\mathrm{mm}$ & 0.0394 \\
1.1209 & lb $/ \mathrm{acre}$ & $\mathrm{kg} \cdot \mathrm{ha}^{-1}$ & 0.8922 \\
4.8824 & lb $/ \mathrm{ft}^{2}$ & $\mathrm{~kg} \cdot \mathrm{m}^{-2}$ & 0.2048 \\
1 & meq/100 g & $\mathrm{cmol} \cdot \mathrm{kg}^{-1}$ & 1 \\
1 & micron $(\mathrm{s})$ & $\mu \mathrm{m}$ & 1 \\
1.6093 & mile $(\mathrm{s})$ & $\mathrm{km}$ & 0.6214 \\
2.2417 & ton $(\mathrm{s}) / \mathrm{acre}$ & $\mathrm{t} \cdot \mathrm{ha}^{-1}$ & 0.4461 \\
$\left({ }^{\circ} \mathrm{F}-32\right) \div 1.8$ & ${ }^{\circ} \mathrm{F}$ & ${ }^{\circ} \mathrm{C}$ & $\left({ }^{\circ} \mathrm{C} \times 1.8\right)+32$
\end{tabular}


markets to supply fresh amaranth throughout the year, which encourages farmers to grow the crop in larger areas under more intensive production practices to increase productivity. As amaranth production shifts from household to commercial scale production, farmers and other value chain actors will want productive, high-yielding amaranth varieties of excellent color, taste, and shelf life that meet market requirements. Despite the importance of amaranth, variety improvement programs in Africa are in early stages. It is only recently that the World Vegetable Center, Shanhua, Tainan, Taiwan (WorldVeg), and other private and public sector organizations have initiated amaranth improvement programs on the continent. Only a few officially released improved varieties have been under commercial production in Tanzania and other parts of East Africa (Dinssa et al., 2016). A deeper understanding of amaranth adaptation to different production environments and seasons help breeders make informed decisions about germplasm choice and

Received for publication 3 Apr. 2019. Accepted for publication 29 May 2019.

Published online 9 July 2019.

Funding for this research was provided by the World Vegetable Center, Innovation Fund Project and longterm strategic donors to the World Vegetable Center: Republic of China (Taiwan), UK aid from the UK government, US Agency for International Development, Australian Centre for International Agricultural Research, Germany, Thailand, Philippines, Korea, and Japan. The publication cost of the paper was covered by the project "DIVERSIFYING FOOD SYSTEMS: Horticultural Innovations and Learning for Improved Nutrition and Livelihood in East Africa" Phase 2, financed by The Federal Ministry for Economic Cooperation and Development (BMZ), Germany (grant number 81202141; Project No. 15.7860.8-001.00). We acknowledge Mary Matovolwa, Salome Mushi, and Raphael Mallogo for their assistance in field operations and data collection.

${ }^{1}$ World Vegetable Center, Eastern and Southern Africa, 10 Duluti, Arusha, Tanzania

${ }^{2}$ World Vegetable Center, West and Central AfricaCoastal and Humid Regions, 08 BP 0932 Tri Postal, Cotonou, Benin

${ }^{3}$ World Vegetable Center, P.O. Box 42, Shanhua, Tainan 741, Taiwan

${ }^{4}$ Mikocheni Agricultural Research Institute, P.O. Box 6226, Dar es Salaam, Tanzania

${ }^{5}$ Tanzania Horticultural Research and Training Institute (Horti-Tengeru), P.O. Box 1253, Arusha, Tanzania

${ }^{6}$ Corresponding author. E-mail: fekadu.dinssa@ worldveg.org.

This is an open access article distributed under the $\mathrm{CC}$ BY-NC-ND license (https://creativecommons.org/ licenses/by-nc-nd/4.0/).

https://doi.org/10.21273/HORTTECH04374-19 identification of locations for selection and variety testing. The objective of this study was to investigate the performances of a set of amaranth entries for vegetable yield over a range of locations and seasons representing different altitudes, weather patterns, soil types, and fertility levels under which amaranth is grown, and to assess the relative contributions of genetic vs. environmental sources of variation for vegetable yield.

\section{Materials and methods}

Plant materials. Twenty-six amaranth entries of seven species were evaluated (Table 1), including five gene bank accessions, 19 lines developed through mass or single plant selection within gene bank accessions at the World Vegetable Center Eastern and Southern Africa, Arusha, Tanzania (WorldVeg-ESA), and two commercial varieties. All entries originated from Africa except one breeding line that was developed by single plant selection from an accession obtained from the United States, and one accession from India.

Trial SEAsons and LOCATIONS. The entries were grown in multilocation trials in Tanzania in 2016 and 2017 during two distinct periods: 1) Mar. to Aug. 2016 (March-May is a rainy period and June-August is relatively cool, referred to hereafter as wet-cool season); and 2) Nov. 2016 to Feb. 2017, which is a dry period with higher temperatures (referred to hereafter as hot-dry season). The following five locations were chosen in Tanzania for the trials: 1) a farmer's field near Moshi city (Moshi) in the Kilimanjaro administrative region; 2) the Chambezi Agricultural Research Station (Chambezi) of the Mikocheni Agricultural Research Institute in the Pwani administrative region in the coastal environment $\approx 60 \mathrm{~km}$ northwest of Dar es Salaam city; 3) WorldVegESA research station; 4) the HortiTengeru research station near Arusha; and 5 ) The Siouxland Tanzania Educational Medical Ministries farm field at Mbuguni about $30 \mathrm{~km}$ southeast of Arusha. Trial locations varied in altitude, weather conditions, and in various soil physical and chemical characteristics (Table 2). Soil particle sizes of each location, on samples collected immediately before transplanting, were determined using pipette or hydrometer method. Total nitrogen was determined using the semimicro Kjeldahl method, and organic carbon was determined by Walkley-Black method. Ammonium acetate method was used to determine cation exchangeable capacity and K-base extraction. Weather conditions available for four trial locations are given in Fig. I for the wet-cool season and in Fig. 2 for the hot-dry season. There was no meteorology station at the Mbuguni location.

EXPERIMENTAL DESIGN, SOWING, AND TRANSPLANTING. The study was carried out in a randomized complete block design in both seasons. Entries were replicated twice in the wet-cool season trials in 2016 due to the small amount of seed available for each entry. Three replications were used in the hot-dry season trials in 201617 using seed multiplied during the wet-cool season of 2016. Each entry in each replication was grown in two rows spaced at $60 \mathrm{~cm}$ apart with 20 plants per row at $25-\mathrm{cm}$ spacing between plants within the row.

Seedlings were raised in seedling trays or seed beds. The wet-cool season trials were sown on 23 and 31 Mar., and transplanted on 10 and 19 Apr. 2016 at Chambezi and WorldVeg-ESA, respectively. Mbuguni, Moshi, and Horti-Tengeru trials were sown on 13,14 , and 21 Apr., and transplanted on 4, 6, and 10 May 2016, respectively. Hot-dry season trials were sown on 11 Nov. 2016 except at Chambezi. The trial at Chambezi was sown on 28 Nov. and transplanted on 19 Dec. 2016. Transplanting at Mbuguni was conducted on 30 Nov. 2016 and carried out on 1, 2, and 6 Dec. 2016 at WorldVegESA, Horti-Tengeru, and Moshi, respectively.

Field Management. Fertilizer $20 \mathrm{~N}-4.4 \mathrm{P}-8.3 \mathrm{~K}$ at the rate of 200 $\mathrm{kg} \cdot \mathrm{ha}^{-1}$, was manually applied as a basal application 1 week after transplanting in all trials. Urea $(46 \mathrm{~N}-0 \mathrm{P}-$ $0 \mathrm{~K})$ at the rate of $120 \mathrm{~kg} \cdot \mathrm{ha}^{-1}$ was applied as side-dressing 3 weeks after transplanting. Decomposed cow dung was applied at the rate of 2.75 $\mathrm{kg} \cdot \mathrm{m}^{-2}$ in the Chambezi trials according to the practice of the location because the soil is low in total soil nitrogen, organic carbon, and clay contents (Table 2). The Mbuguni trials were conducted on-farm, and chemical fertilizers were applied in the 


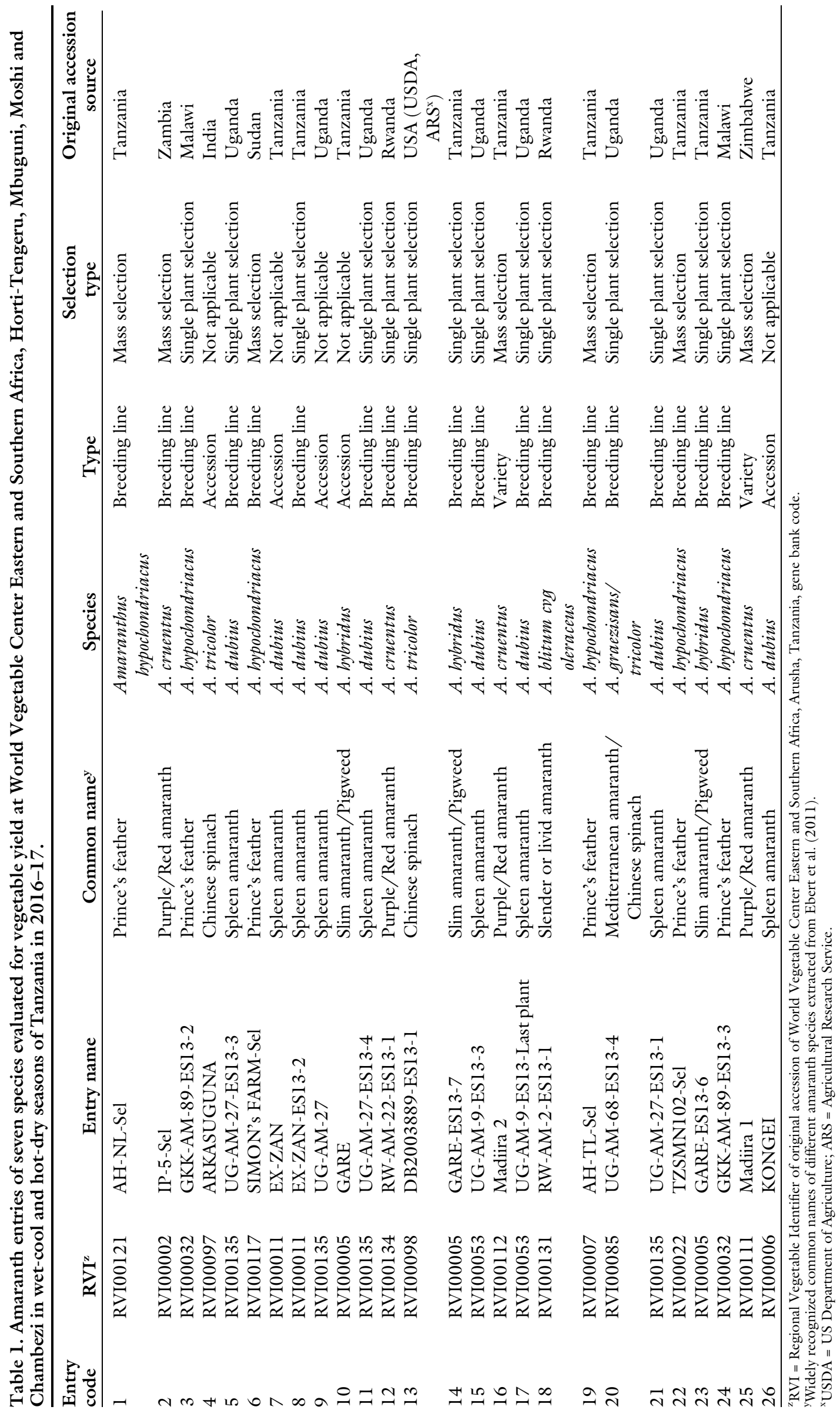


Table 2. Soil chemical and physical characteristics of five trial locations, measured on samples taken before planting, at which 26 amaranth entries were evaluated in wet-cool and hot-dry seasons of Tanzania in 2016.

\begin{tabular}{|c|c|c|c|c|c|}
\hline Soil characteristics ${ }^{\mathrm{z}}$ & WorldVeg-ESA & Horti-Tengeru & Mbuguni & Moshi & Chambezi \\
\hline \multicolumn{6}{|l|}{ Soil chemical characteristics } \\
\hline Total nitrogen $(\%)$ & 0.17 & 0.22 & 0.21 & 0.10 & 0.09 \\
\hline Organic carbon $(\%)$ & 1.40 & 3.30 & 1.82 & 1.03 & 0.87 \\
\hline Potassium (meq/100 g) & 0.23 & 0.29 & 0.25 & 0.63 & 0.35 \\
\hline Phosphorus (meq/100 g) & 5.15 & 5.64 & 3.69 & 5.36 & 3.57 \\
\hline $\mathrm{pH}($ water $)$ & 6.50 & 7.35 & 7.30 & 6.50 & 7.40 \\
\hline Very coarse sand: $1000-2000 \mu \mathrm{m}(\%)$ & 13.03 & 9.63 & 9.19 & 13.73 & 5.69 \\
\hline Coarse sand: $500-1000 \mu \mathrm{m}(\%)$ & 7.18 & 7.03 & 7.56 & 4.08 & 20.81 \\
\hline Medium sand: $250-500 \mu \mathrm{m}(\%)$ & 2.46 & 2.79 & 4.12 & 3.11 & 24.80 \\
\hline Fine sand: $100-250 \mu \mathrm{m}(\%)$ & 3.72 & 4.75 & 4.05 & 1.40 & 18.59 \\
\hline Very fine sand: $50-100 \mu \mathrm{m}(\%)$ & 1.10 & 0.80 & 0.08 & 0.18 & 0.12 \\
\hline Coarse silt: $20-50 \mu \mathrm{m}(\%)$ & 12.50 & 12.50 & 10.00 & 20.00 & 7.50 \\
\hline
\end{tabular}

${ }^{\mathrm{z}} 1 \mathrm{meq} / 100 \mathrm{~g}=1 \mathrm{cmol} \cdot \mathrm{kg}^{-1}, 1 \mu \mathrm{m}=1$ micron.

${ }^{\mathrm{y}}$ WorldVeg-ESA $=$ World Vegetable Center Eastern and Southern Africa (Arusha, Tanzania: lat. $3.4^{\circ} \mathrm{S}$, long. $36.8^{\circ} \mathrm{E}$, elevation $\left.1235 \mathrm{~m}\right)$, Horti-Tengeru (lat. $3.4^{\circ} \mathrm{S}$, long. $36.8^{\circ} \mathrm{E}$, elevation $1213 \mathrm{~m}$ ), Mbuguni (lat. $3.5^{\circ} \mathrm{S}$, long. $36.9^{\circ} \mathrm{E}$, elevation $933 \mathrm{~m}$ ), Moshi (lat. $3.4^{\circ} \mathrm{S}$, long. $37.5^{\circ} \mathrm{E}$, elevation $866 \mathrm{~m}$ ), Chambezi (lat. $6.2^{\circ} \mathrm{S}$, long. $38.5^{\circ} \mathrm{E}$, elevation $39 \mathrm{~m}) ; 1 \mathrm{~m}=3.2808 \mathrm{ft}$.

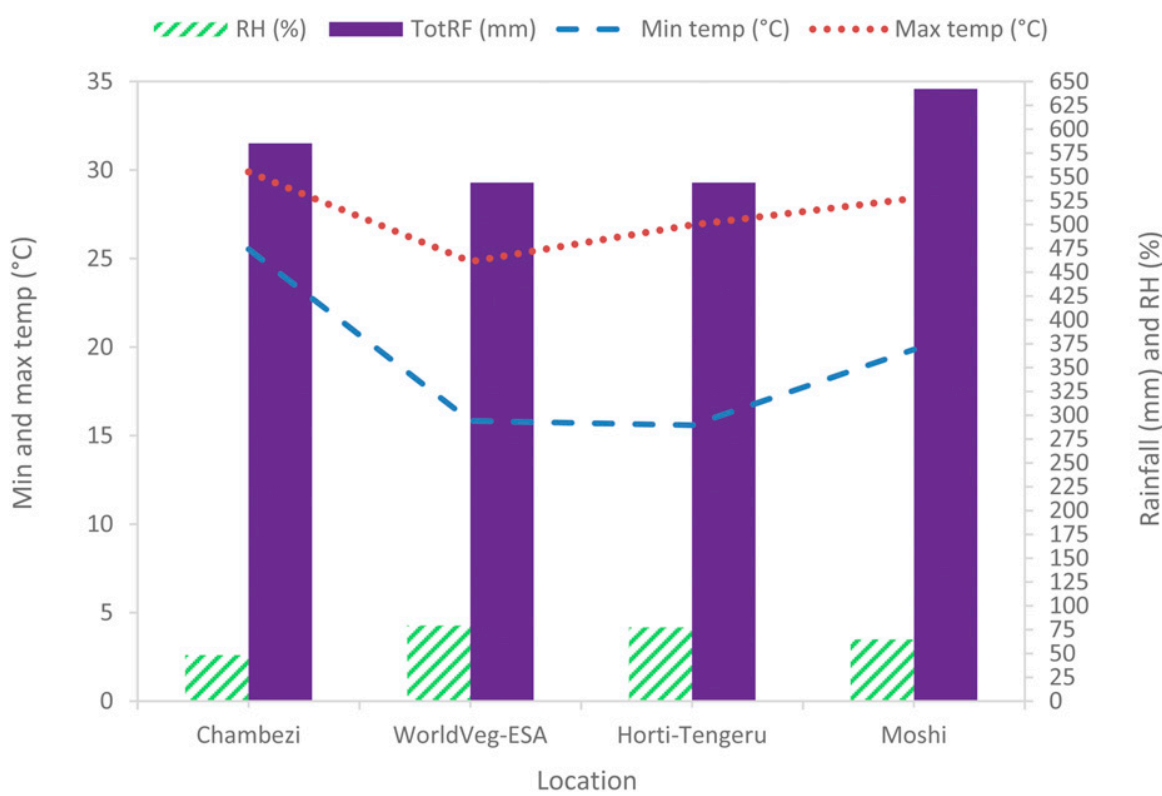

Fig. 1. Mean minimum (Min) and maximum (Max) temperatures, relative humidity $(\mathrm{RH})$, and total rainfall (TotRF) of four locations during the wet-cool season trials, Mar. to Aug. 2016 in Tanzania. Locations details are as follows: Chambezi (lat. 6.2 ${ }^{\circ} \mathrm{S}$, long. $38.5^{\circ} \mathrm{E}$, elevation $39 \mathrm{~m}$ ), WorldVeg-ESA = World Vegetable Center Eastern and Southern Africa Arusha, Tanzania (lat. 3.4 ${ }^{\circ} \mathrm{S}$, long. $36.8^{\circ} \mathrm{E}$, elevation $1235 \mathrm{~m}$ ), Horti-Tengeru (lat. $3.4^{\circ} \mathrm{S}$, long. $36.8^{\circ} \mathrm{E}$, elevation $1213 \mathrm{~m}$ ) and Moshi (lat. $3.4^{\circ} \mathrm{S}$, long. $37.5^{\circ} \mathrm{E}$, elevation $866 \mathrm{~m}$ ); $1 \mathrm{~m}=3.2808 \mathrm{ft}$, ${ }^{\circ} \mathrm{C}=\left({ }^{\circ} \mathrm{F}-32\right) \div 1.8,1 \mathrm{~mm}=0.0394$ inch.

wet-cool trial but were withheld during the hot-dry season trial because the farm owner decided to switch to organic farming methods and only crop residues were incorporated before transplanting; this difference between the seasons was considered as an environmental difference.
Data collection. Marketable vegetable yield was harvested from the 18 central plants per row in each plot and plants were subjected to multiple harvests. The harvest was conducted by topping approximately one-third of the plant main stem and branches from the apex measured on the main stem during the first harvest, and from the stem nodes on which branches appeared in subsequent harvests. The first harvest of the wet-cool season and hot-dry season trials was conducted about 25 and $20 \mathrm{~d}$ after transplanting, respectively; subsequent harvests occurred at $\approx 12$-d intervals thereafter. A total of five harvests were performed in each trial. Additional data collected at all locations in both seasons based on three randomly selected plants per plot included plant height (centimeters) measured from the ground level to the growing tip; number of branches per plant; leaf length (centimeters) and width (centimeters) measured from three fully developed leaves per each of three randomly taken plants at each marketable vegetable yield harvest. Days to flowering of each entry was determined at WorldVeg-ESA in seed increase plots from which vegetative harvest was not conducted; it was not possible to regularly visit and collect flowering data at the other locations because of the large distances from the breeding station of WorldVeg-ESA.

Statistical analysis. All statistical analyses were run in GenStat (release 19.1; VSN International, Hemel Hempstead, UK). Data were tested for homogeneity of variance and normal distribution to meet the assumptions of analysis of variance (ANOVA). No major deviations from 


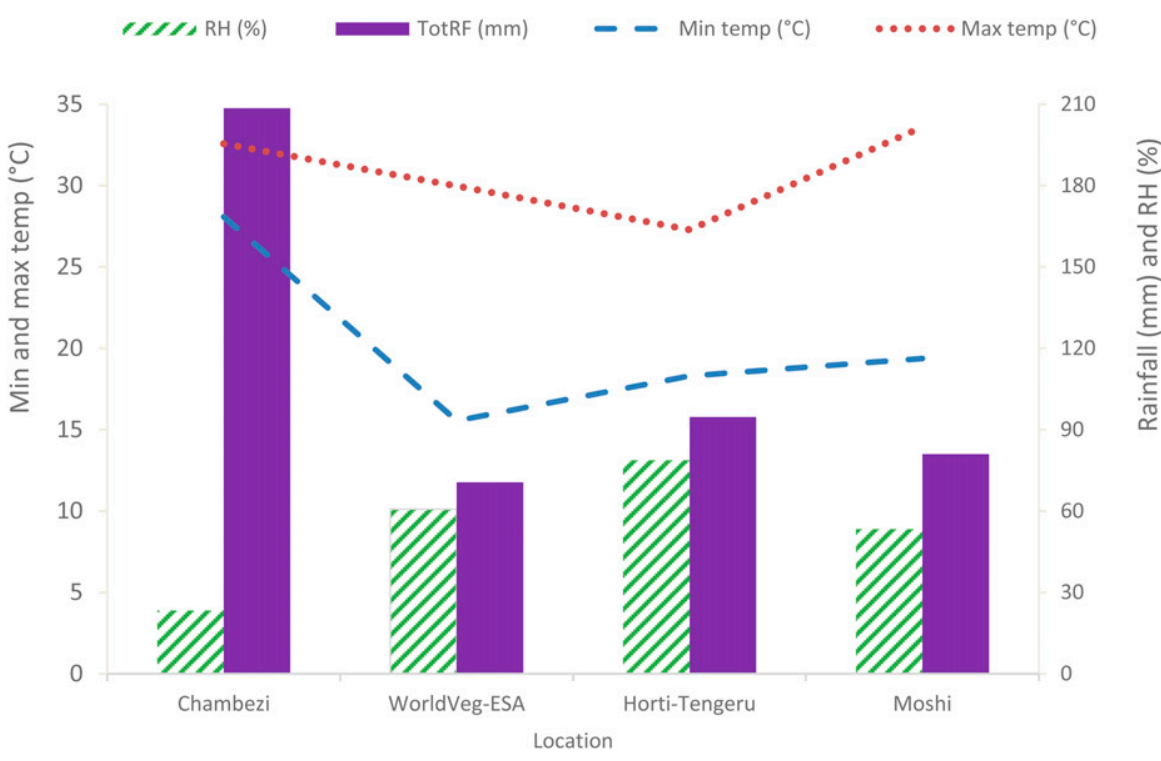

Fig. 2. Mean minimum (Min) and maximum (Max) temperatures, relative humidity (RH), and total rainfall (TotRF) of four locations during the hot-dry season trials, Nov. 2016 to Feb. 2017 in Tanzania. Locations details are as follows: Chambezi (lat. $6.2^{\circ} \mathrm{S}$, long. $38.5^{\circ} \mathrm{E}$, elevation $39 \mathrm{~m}$ ), WorldVeg-ESA = World Vegetable Center Eastern and Southern Africa, Arusha, Tanzania (lat. 3.4 ${ }^{\circ}$, long. $36.8^{\circ} \mathrm{E}$, elevation $1235 \mathrm{~m}$ ), Horti-Tengeru (lat. $3.4^{\circ} \mathrm{S}$, long. $36.8^{\circ} \mathrm{E}$, elevation $1213 \mathrm{~m}$ ), and Moshi (lat. 3.4 ${ }^{\circ} \mathrm{S}$, long. $37.5^{\circ} \mathrm{E}$, elevation $866 \mathrm{~m}$ ); $1 \mathrm{~m}=3.2808 \mathrm{ft}$, ${ }^{\circ} \mathrm{C}=\left({ }^{\circ} \mathrm{F}-32\right) \div 1.8,1 \mathrm{~mm}=0.0394$ inch.

the assumptions of ANOVA were detected. Individual ANOVA of each trial and combined ANOVA were conducted on vegetable yield using the Generalized Linear Mixed Model procedure of GenStat (release 19.1) following a randomized complete block design. To achieve balanced data sets for combined analysis (entry $x$ location $\times$ season), both replications of the wet-cool season trials and replications one and two of the hot-dry season trials were used. The three replications of the hot-dry season were used in individual location ANOVA, in analysis conducted across locations in the season, and in genotype $(\mathrm{G})$ and $\mathrm{G}$ by environment (E) interaction (GGE) biplot analysis. Following Yan and Tinker (2006), the GGE biplot analysis that focuses on genotype and genotype by environment interaction was used to evaluate genotypes and test environments by analyzing and graphically displaying them simultaneously. The traditional genotypes by environment interaction (GEI) analysis was used to estimate the proportion of the main effects of genotype, location, and season and their interaction effects.

ANOVA across locations in each season was conducted using the
Additive Main Effects and Multiplicative Interactions (AMMI) model in GenStat (release 19.1). The AMMI model (Zobel et al., 1988) uses the traditional ANOVA to first fit the additive main effects of genotype and environment, and then describes the nonadditive multiplicative part (GEI) by interaction principal component axes (IPCAs). Two IPCAs that significantly explained the partitioned GEI sum of squares (SS) were considered in the AMMI analysis. The AMMI model used to analyze GEI is as follows: $\Upsilon_{i j r}=\mu+g_{i}+e_{j}+$ $\Sigma \lambda_{x} \alpha_{i x} \sigma_{j x}+R_{i j}+K_{r(j)}+\varepsilon_{i j r}$, where $\Upsilon_{i j r}$ is the value of $i^{\text {th }}$ entry in $j^{\text {th }}$ location for replicate $r, \mu$ is grand mean, $g_{i}$ is mean of the $i^{t h}$ entry, $e_{j}$ is mean of the $j^{\text {th }}$ location, $\lambda_{x}$ is singular value for principal component (PC) axis $x, \alpha_{i x}$ is PC scores for axis $x$ of the $i^{t h}$ entry, $\sigma_{j x}$ is PC scores for axis $x$ of the $j^{\text {th }}$ location, $R_{i j}$ is residual that remains after fitting some of PC axes ( $R_{i j}$ value becomes zero when full model is fitted), $K_{r(j)}$ is block effect for replication $r$ for an RCB design within location $j$, and $\varepsilon_{i j r}$ is error term.

The GGE biplot analysis (Yan and Kang, 2002), following environment-centered model in GeneStat (Release 19.1), was used to identify
MEs and winner entries at different locations.

Pearson's correlation coefficients between environmental covariates (soil characteristics, altitude, and geographic coordinates) and AMMI-generated location IPCA scores were obtained. This was to identify which environmental factor(s) had more contribution to the GEI and influence on the vegetable yield. Pearson's correlation coefficient analysis was also conducted between vegetable yield and plant traits (plant height, number of branches, leaf length, and leaf width).

\section{Results}

INDIVIDUAL AND COMBINED ANOVAs. Individual ANOVA indicated highly significant differences among entries in two of the five wetcool season trials, and in four of the five hot-dry season trials (Table 3 ). Trial mean yields across entries ranged from $11.5 \mathrm{t} \cdot \mathrm{ha}^{-1}$ (Moshi) to $24.7 \mathrm{t} \cdot \mathrm{ha}^{-1}$ (Horti-Tengeru) in the wet-cool season trials, and from 16.4 $\mathrm{t} \cdot \mathrm{ha}^{-1}$ (Mbuguni) to $32.0 \mathrm{t} \cdot \mathrm{ha}^{-1}$ (Moshi and Chambezi) in the hot-dry season trials. In all locations except Mbuguni the mean yield across entries was greater in the hot-dry season than in the wet-cool season; the percent increase ranged from $22.7 \%$ at Horti-Tengeru to $178.3 \%$ at Moshi. DB2003889-ESI3-1 and UG-AM9-ES13-3 gave the highest mean vegetable yield across locations in the wet-cool and hot-dry season trials, respectively (Table 3 ).

Combined ANOVA involving entry, location, and season indicated highly significant differences $(P<$ 0.001 ) among entries, locations, and between season main effects. Moreover, entry $\times$ location, entry $\times$ season, location $\times$ season, and entry $\times$ location $\times$ season interaction effects were highly significant $[P \leq 0.002$ (data not shown)]. Season explained the highest proportion $(52.1 \%)$ of the total sum of squares of the main effects (entry + location + season effects), whereas entry and location accounted for $24.9 \%$ and $23.0 \%$, respectively.

AMMI ANALYsIs. AMMI analysis conducted by season partitioned the entry-by-location interaction sums of squares into two significant or highly significant IPCAs in each 


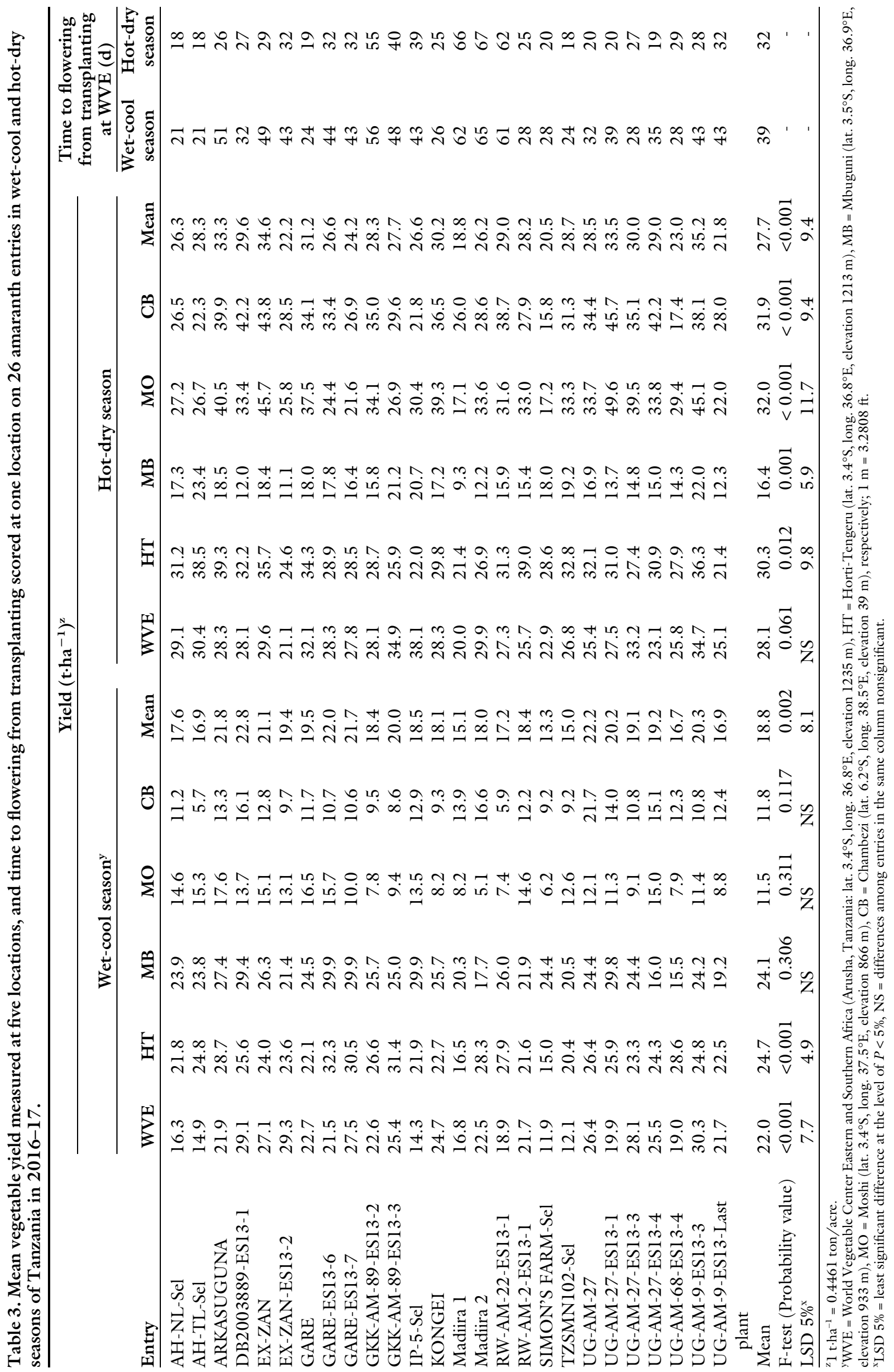


Table 4. Additive main effect and multiplicative interaction (AMMI) analysis of variance for two significant interaction principal component axes (IPCAs) on vegetable yield of 26 amaranth entries of seven species evaluated across five locations during each of wet-cool season and hot-dry season of Tanzania in 2016-17.

\begin{tabular}{|c|c|c|c|c|c|c|}
\hline Source of variation & df & Sum of square & Mean square & $\begin{array}{c}F- \\
\text { test }\end{array}$ & Probability & $\begin{array}{c}\text { Proportion } \\
\text { of sum of } \\
\text { square }(\%)^{\mathrm{z}}\end{array}$ \\
\hline \multicolumn{7}{|l|}{ Wet-cool season, 2016} \\
\hline Entry $(\mathrm{G})$ & 25 & 1415 & 56.6 & 3.47 & $<0.001$ & 10.5 \\
\hline Location $(\mathrm{L})$ & 4 & 9117 & 2279.3 & 75.11 & $<0.001$ & 67.9 \\
\hline Replication within L & 5 & 152 & 30.3 & 1.86 & 0.106 & \\
\hline IPCAl & 28 & 1147 & 41 & 2.51 & $<0.001$ & 39.7 \\
\hline IPCA2 & 26 & 797 & 30.7 & 1.88 & 0.012 & 27.6 \\
\hline Residuals & 46 & 947 & 20.6 & 1.26 & 0.159 & \\
\hline Error & 125 & 2042 & 16.3 & & & \\
\hline Total & 259 & 15618 & 60.3 & & & \\
\hline \multicolumn{7}{|c|}{ Hot-dry season, 2016-17 } \\
\hline $\mathrm{G} \times \mathrm{L}$ & 100 & 7383 & 73.8 & 2.25 & $<0.001$ & 27.0 \\
\hline IPCAl & 28 & 4614 & 164.8 & 5.02 & $<0.001$ & 62.5 \\
\hline IPCA2 & 26 & 1403 & 54 & 1.65 & 0.029 & 19.0 \\
\hline Residual & 46 & 1366 & 29.7 & 0.91 & 0.648 & \\
\hline Error & 250 & 8200 & 32.8 & & & \\
\hline Total & 389 & 36424 & 93.6 & & & \\
\hline
\end{tabular}

${ }^{\mathrm{z}}$ The proportions of the sum of squares (SS) of entry, location and G $\times$ L interaction were calculated from treatment SS; the proportion of the SS of IPCAs and residuals were calculated from $\mathrm{G} \times \mathrm{L}$ interaction $\mathrm{SS}$.

season (Table 4). In both the wetcool and hot-dry seasons, the highest sum of squares of treatment was explained by location followed by the entry $\times$ location interaction. In the wet-cool season, the two IPCAs together explained $67.3 \%$ of the sum of squares of entry $\times$ location interaction, with IPCA1 and IPCA2 accounting for $39.7 \%$ and $27.6 \%$, respectively. The remaining nonsignificant IPCAs were assigned to the residual term. The two significant IPCAs in the hot-dry season explained $81.5 \%$ of the sum of squares of entry $\times$ location interaction effect with IPCA1 and IPCA2 explaining $62.5 \%$ and $19.0 \%$, respectively. The AMMI analysis identified the first four best-yielding entries per location in each season (Table 5). Many of the top four entries identified at a location in each season were among the top entries in one or more other locations in the same season. However, most of the best entries identified in one season were not always the best in the other season. DB2003889ES13-1 and UG-AM-27, for example, were among the best four selected entries in four and three of the five wet-cool season trials, respectively, but DB2003889-ES13-1 appeared only once and UG-AM-27 was absent among the best four entries in the hot-dry season trials. Likewise, UG-AM-9-ESI3-3 was selected in four of the five hot-dry season trials but was selected in only one wet-cool season trial. In the hot-dry season, all locations except Moshi did not share any of their best four entries with Chambezi location (Table 5); Chambezi followed by Moshi had the highest minimum and maximum temperatures in both seasons.

M E G A - E N V I R O N M E N T IDENTIFICATION. Figure 3 shows a GGE biplot constructed using the hot-dry season trials data that were obtained from three replications. The GGE biplot analysis grouped the five locations into two MEs. The first ME (ME 1) encompassed the Chambezi location that is located in the lowaltitude coastal region, and the Moshi location. Moshi stands second after Chambezi for its high temperatures, low relative humidity, and low altitude when compared with the other locations (Figs. 1-2, Table 2). The three higher-altitude locations,
WorldVeg-ESA, Horti-Tengeru, and Mbuguni, formed a second ME (ME 2). Although multiple years of testing is important to decide whether target environments can be divided into different MEs, the differences between the locations grouped in MEl and those in ME2 in altitude, temperatures, humidity, and longitude support the current classification of the locations. An ME is a group of environments with similar physical and climate features such that a variety adapted to one of the environments is likely to be adapted to the others (Yan and Rajcan, 2002). The CIMMYT wheat (Triticum sp.) breeding program, for example, clusters global wheat production environments based on soil characteristics, moisture, altitude, geographical coordinates, weather conditions, and biotic and abiotic stresses (Rajaram et al., 1994).

The "which-won-where" view of the GGE biplot (Yan et al., 2007) consists of an irregular polygon and a set of lines drawn from the biplot origin intersecting each of the polygon sides at right angles. Genotypes farthest away from the origin of the 
Table 5. The four best amaranth entries for vegetable yield by location and season selected by the additive main effect and multiplicative interaction (AMMI) analysis based on two significant interaction principal component axes (IPCAs) measured on 26 amaranth entries evaluated during wet-cool season and hot-dry season of Tanzania in 2016-17.

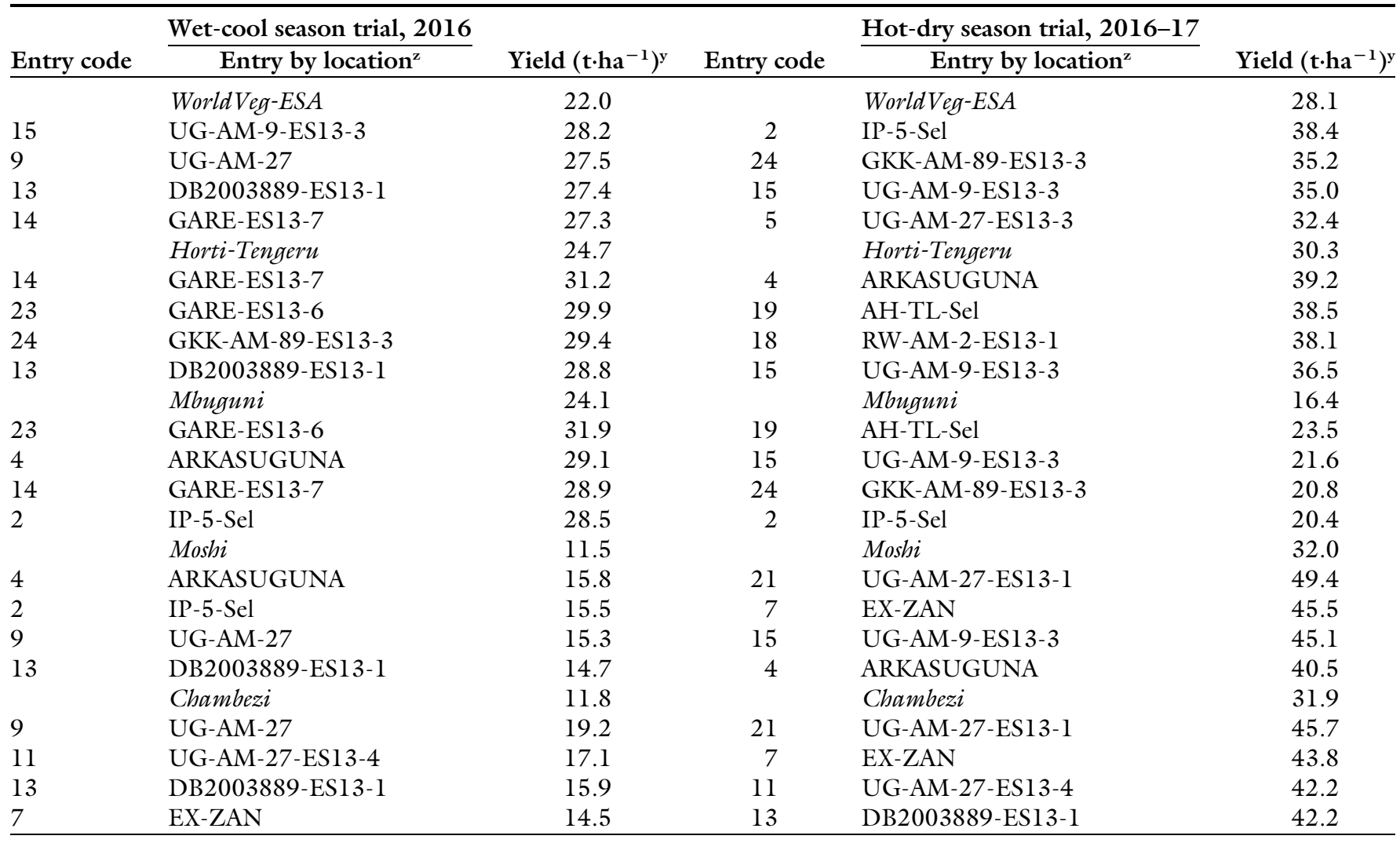

${ }^{\mathrm{z}}$ WorldVeg-ESA $=$ World Vegetable Center Eastern and Southern Africa (Arusha, Tanzania: lat. $3.4^{\circ} \mathrm{S}$, long. $36.8^{\circ} \mathrm{E}$, elevation $\left.1235 \mathrm{~m}\right)$, Horti-Tengeru (lat. $3.4^{\circ} \mathrm{S}$, long. $36.8^{\circ} \mathrm{E}$, elevation $1213 \mathrm{~m}$ ), Mbuguni (lat. $3.5^{\circ} \mathrm{S}$, long. $36.9^{\circ} \mathrm{E}$, elevation $933 \mathrm{~m}$ ), Moshi (lat. $3.4^{\circ} \mathrm{S}$, long. $37.5^{\circ} \mathrm{E}$, elevation $\left.866 \mathrm{~m}\right)$, and Chambezi (lat. $6.2^{\circ} \mathrm{S}$, long. $38.5^{\circ} \mathrm{E}$, elevation $39 \mathrm{~m}) ; 1 \mathrm{~m}=3.2808 \mathrm{ft}$.

${ }^{\mathrm{y}} \mathrm{l} \mathrm{t} \cdot \mathrm{ha}^{-1}=0.446 \mathrm{l}$ ton/acre.

GGE biplot are located on the vertices of the polygon in various directions, such that all the remaining genotype are contained within the polygon (Yan et al., 2007). According to Yan and Tinker (2006), entries far from the GGE biplot origin, including those on the vertices of the polygon, make large contributions to GEI, whereas entries near the origin of the biplot are more stable across environments and contribute less to GEI. Locations far from the origin have high potential to identify entries adapted to different environments. In Fig. 3, Chambezi and Moshi locations were positioned relatively far from the GGE biplot origin as compared with the other three locations, indicating their high discriminative potential in identifying entries. Entries such as 15 (UG-AM-9-ESI3-3) and 25 ('Madiira l') on the vertices of the polygon performed either the best or the poorest in one or more locations. Entry 25 was the poorest in almost all locations, whereas entry 15 was among the best performers at all locations except Chambezi. The perpendicular lines (also called equality lines) divide the GGE biplot into sectors of environments such that the best genotype for each sector environment is identified (Yan and Tinker, 2006). The GGE biplot in Fig. 3 divided the locations into three sectors, although Mbuguni was clustered with WorldVeg-ESA and HortiTengeru. The equality line between entry 15 and entry 21 indicates that entry 15 performed better than entry $2 \mathrm{l}$ at WorldVeg-ESA, Horti-Tengeru, and Mbuguni, whereas the reverse occurred at Moshi and Chambezi. Entry 19 was the winner at Mbuguni. The results of this GGE biplot agree with the AMMI selection results (Table 5).

Correlation analysis. Significant correlation coefficients were found in the wet-cool season between location IPCAl score and the amount of very fine sand in the soil $(r=$ $\left.0.87^{*}\right)$, between IPCA2 and total soil nitrogen $\left(r=-0.98^{* *}\right)$, and between IPCA2 and longitude $\left(r=0.92^{*}\right) ;{ }^{*}=$ significant at $0.01<P<0.05$, and ${ }^{* *}=$ significant at $P<0.01$. Table 2 shows a list of location covariates or factors. In the hot-dry season, location IPCAl score was positively correlated with longitude $\left(r=0.88^{*}\right)$, and IPCA2 with soil $\mathrm{pH}$. The correlation results suggest that the GEI effect and differences in productivity among the locations in both seasons were mainly caused by their differences in longitude, and total soil nitrogen content. Moreover, the amount of very fine sand content in the soil and soil $\mathrm{pH}$ also played a role in the wet-cool season and hot-dry season, respectively. We observed many correlation coefficients between IPCAs and environmental covariates with relatively high absolute $r$-values, for example, $r=-0.818$ between altitude and location IPCA2 score, which may be considered "strong" but was not significant. The reason for this was the small sample size (i.e., number of 


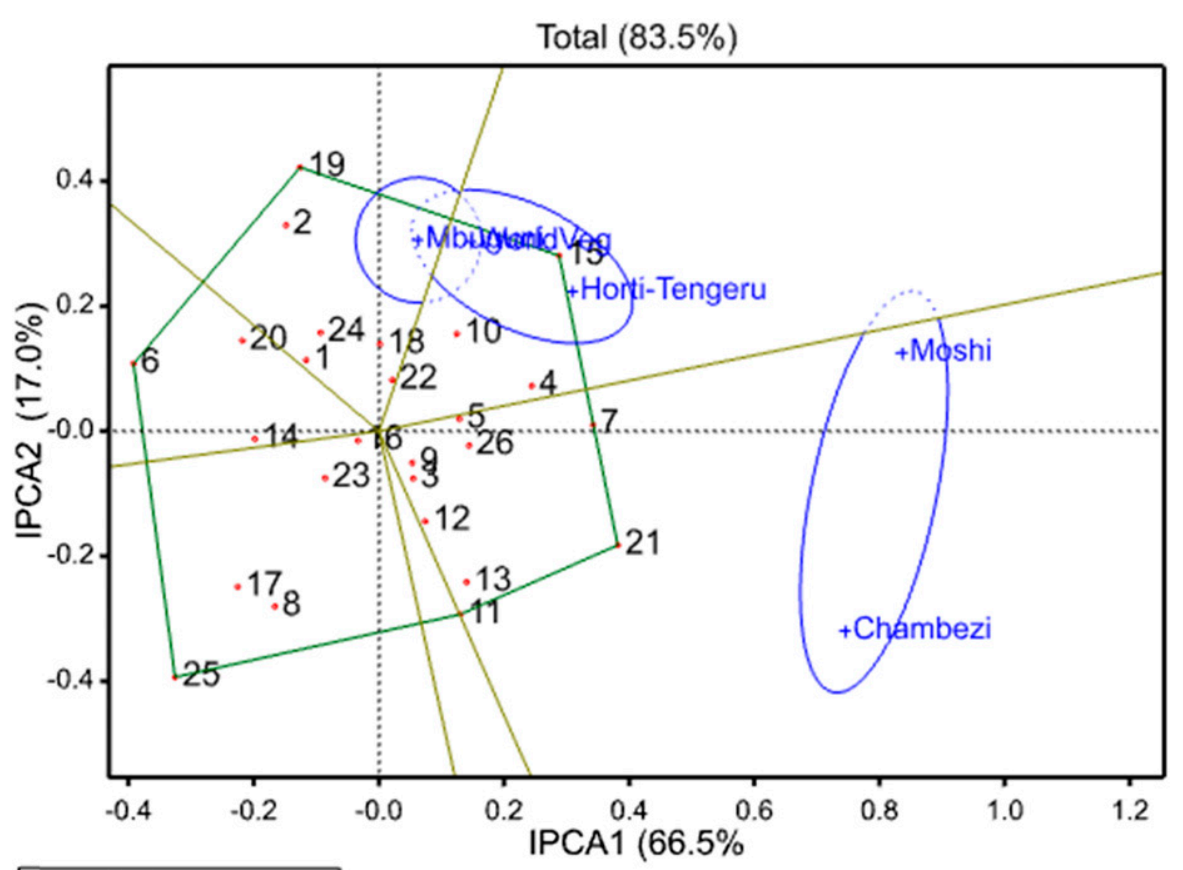

$\begin{array}{ll}* & \text { Genotype scores } \\ + & \text { Environment scores } \\ & \text { Convex hull } \\ & \text { Sectors of convex hull } \\ & \text { Mega-Environments }\end{array}$

Fig. 3. Entry and entry-by-location interaction (GGE) biplot of marketable vegetable yield measured on 26 amaranth entries of seven species grown across five locations in the hot-dry season of Tanzania in 2016-17. The locations are World Vegetable Center Eastern and Southern Africa, Arusha, Tanzania, shortened in the graph as WorldVeg (lat. 3.4 ${ }^{\circ} \mathrm{S}$, long. $36.8^{\circ} \mathrm{E}$, elevation $1235 \mathrm{~m}$ ), HortiTengeru (lat. $3.4^{\circ} \mathrm{S}$, long. $36.8^{\circ} \mathrm{E}$, elevation $1213 \mathrm{~m}$ ), Mbuguni (lat. $3.5^{\circ} \mathrm{S}$, long. $36.9^{\circ} \mathrm{E}$, elevation $933 \mathrm{~m}$ ), Moshi (lat. $3.4^{\circ} \mathrm{S}$, long. $37.5^{\circ} \mathrm{E}$, elevation $866 \mathrm{~m}$ ), and Chambezi (lat. $6.2^{\circ} \mathrm{S}$, long. $38.5^{\circ} \mathrm{E}$, elevation $39 \mathrm{~m}$ ); $1 \mathrm{~m}=3.2808 \mathrm{ft}$. The two overlapping location names difficult to read in the three locations' cluster read Mbuguni and WorldVeg. IPCA = interaction principal component axis. See Table 1 for corresponding entry names of the 1-26 entry codes.

locations) and therefore the test was not powerful enough or sufficient to attain a significant test level, and we consider this as a limitation of the study. Adding more locations may be warranted in future studies to better define the association between productivity and environmental factors.

Correlation analysis between vegetable yields and horticultural traits identified significant and positive correlations between leaf width and vegetable yield at Moshi $\left(r=0.42^{*}\right)$ and WorldVeg-ESA $\left(r=0.54^{* *}\right)$ in the wet-cool season, and at all the hot-dry season locations: WorldVegESA $\left(r=0.47^{*}\right)$, Mbuguni $(r=$ $0.49 *)$, Chambezi $\left(r=0.50^{* *}\right)$, Horti-Tengeru $\left(r=0.69^{* *}\right)$, and Moshi $\left(r=0.87^{* *}\right)$. A. dubius entries (EX-ZAN, UG-AM-9-ESI33 , and UG-AM-27-ESI3-1), and A. tricolor (DB2003889-ES13-1 and ARKASUGUNA) were among entries with relatively wider leaves, $\left.0.51^{* *}\right)$, Horti-Tengeru $\left(r=0.43^{*}\right)$, and Moshi $\left(r=0.50^{* *}\right)$, and at Moshi in the hot-dry season $\left(r=0.64^{* *}\right)$. Yield was not significantly correlated with plant height except at Chambezi $\left(r=0.43^{*}\right)$ and Mbuguni $(r=$ $\left.0.59^{* *}\right)$ in the hot-dry season.

\section{Discussion}

Information about amaranth germplasm adaptation to different environments, the relative contribution of genotype, importance of environment, and genotype by environment interaction will help improve breeding efficiency and lead to improved variety development. In this study, 26 diverse amaranth entries of different species were grown in replicated trials to assess their performance in vegetable yield when grown across five diverse Tanzanian locations differing in altitude, geographic coordinate, soil properties, and weather conditions, and in two distinct seasons, wet-cool and hot-dry seasons, and to characterize selection sites for different target amaranth production environments.

The importance of season on amaranth vegetable yield was evident, as its effects accounted for slightly more than $50 \%$ of the sum of squares of the main effects. In this study, mean yield $\left(27.7 \mathrm{t} \cdot \mathrm{ha}^{-1}\right)$ across the hot-dry season trials was $47.3 \%$ greater than the mean yield (18.8 $\mathrm{t} \cdot \mathrm{ha}^{-1}$ ) over the wet-cool season trials. A prediction study related to climate change indicated that the production of $A$. cruentus, $A$. bypochondriacus, and their wild relatives $(A$. bybridus and $A$. powellii) is expected to increase in higher-temperature regions, and that temperature is the main climatic variable affecting amaranth adaptation (Escobedo-Lopez et al., 2014). Amaranth is a $\mathrm{C}_{4}$ plant capable of high photosynthesis rates at high solar radiation, temperatures as high as $40{ }^{\circ} \mathrm{C}$, and it grows well at a temperature range of 25 to $33{ }^{\circ} \mathrm{C}$ with slower growth below $18{ }^{\circ} \mathrm{C}$ (Das, 2016; Grubben, 2004a, 2004b, $2004 \mathrm{c})$. The average daily temperatures $\left({ }^{\circ} \mathrm{C}\right)$ of wet-cool vs. hot-dry season in this study were 28.0 vs. $30.5,24.0$ vs. $26.5,20.5$ vs. 23.0 , and 21.5 vs. 22.5 at Chambezi, Moshi, WorldVeg-ESA, and HortiTengeru, respectively. The low mean yields at Chambezi and Moshi during the wet-cool season were at least 
partially attributed to the high rainfall received at these locations $[585 \mathrm{~mm}$ at Chambezi and $642 \mathrm{~mm}$ at Moshi (Fig. 1)] that may have caused excessive soil nutrient leaching or reduced root growth. Amaranth grows in a wide range of soil types but is better adapted to well-drained soils rich in organic matter (Das, 2016).

In Tanzania and most other subSaharan Africa countries, amaranth is grown throughout the year if irrigation water is available or rain is reliable. Vegetable amaranth requires moisture throughout the season as opposed to grain amaranth that may perform well with limited moisture once seedlings are established (Das, 2016). Moisture deficit was not a problem in the present study, as irrigation was available. As many farmers in Tanzania and other countries in Africa, however, lack irrigation facilities, water shortages would pose a risk for dry season production. It is important for amaranth breeders to assess the likelihood of developing varieties broadly adapted to environments differing in a range of moisture regimens.

AMMI analysis selected four top-yielding entries at each location and season, and in only a few cases did entries overlap for both the wet-cool and hot-dry seasons at a location. Only at Chambezi three of the four best entries were common to both seasons. At WorldVeg-ESA, Mbuguni, and Moshi only one of the best four entries was common to the two seasons. These results point to variable entry responses to season and suggest that a best amaranth variety in one season may not necessarily be the best in another season. Some AMMI-selected entries such as DB2003889-ES13-1 in the wet-cool season and UG-AM-9-ES13-3 in the hot-dry season that were common to multiple locations in a given season indicate adaptation across locations within season. However, some entries performed well in both seasons, although not always at the same location. Amaranth breeding programs, therefore, may consider developing varieties targeted to a particular season, or identify a pool of varieties well-adapted to one season such as hot-dry season and test them for reasonable performance in the other season. Commercial seed production and marketing costs would be lower for widely adapted varieties that could be sold regionally compared with the production and marketing costs of a larger number of narrowly adapted varieties sold in specific areas or seasons.

Environments with similar or the same agroecological conditions tend to cluster into the same ME (Simane et al., 1999; Yan and Rajcan, 2002). Chambezi and Moshi locations clustered in MEl are generally characterized by low altitudes and higher mean temperatures. Chambezi is characterized by sandy soil with less soil nitrogen, organic carbon and clay contents, and generally less fertile soils. ME2 locations shared the same agroecological conditions (Environment Division, 2007) and are characterized by relatively higher altitudes with lower mean temperatures and have more fertile soils. Each ME may serve as the initial selection site for their respective target environment in Tanzania and other countries that share similar environmental conditions. For the World Vegetable Center Eastern and Southern Africa, Arusha, Tanzania, the present research station is a suitable selection site to identify amaranth varieties adapted to high-altitude areas, and establishment of a second selection site at Chambezi or other coastal location would be useful to identify varieties suitable for low-altitude areas with relatively high temperatures.

Seven amaranth species were included in the current study but the entry number per species was too few to adequately represent within-species genetic diversity for comparison. It is, however, interesting to speculate about possible physiological differences among species. A. dubius is a polyploid with the somatic chromosome number of 64, whereas $A$. bypochondriacus has 32 chromosomes, and $A$. cruentus and $A$. tricolor each has 34 chromosomes (Bonasora et al., 2013). A. dubius is amenable to multiple harvests and is widely grown in Zanzibar and other coastal areas of Tanzania (F.F. Dinssa, personal observation). It grows from sea level to 2000-m elevation (Grubben, 2004b), and varieties of this amaranth are becoming very popular among farmers in Kilimanjaro and Arusha regions, $\approx 1300$-m elevation (F.F. Dinssa, personal observation). Farmer-preferred local varieties of $A$. dubius have ovate or rhomboid-ovate leaf blades, dark green leaf color, and high rejuvenation ability from repeat harvests in a single planting season, but their small plant architecture results in low yields compared with improved varieties. Tanzanian farmers prefer high-yielding $A$. dubius varieties combining desired leaf traits such as green to deep green colors that are characteristics of their local varieties. A. dubius line UG-AM-9-ESl3-3, one of the top four entries in four locations in the hot-dry season trials, has potential for direct release as commercial variety and/or use in breeding programs. Pink-red leaf color type $A$. tricolor is commonly grown in Uganda, whereas the green leaf type is acceptable in other countries in sub-Saharan Africa. A. tricolor line DB2003889-ES13-1 (green leaf type) has high potential for adaptation across locations in the wet-cool season, and could be used in breeding for relatively wet and cool environments. The accession from which the line DB2003889-ES13-1 developed was originated from the United States, whereas the line UG-AM-9ES13-3 was derived from a Ugandan accession.

Plant traits associated with yield can be useful for selection in breeding, especially if enhancement of such traits also improves market preferred quality traits such as leaf size and leaf color type and intensity of a color type such as deep green or light green. Based on farmer participatory selection trials at WorldVeg-ESA (F.F. Dinssa, unpublished data) and observation of products in the market, broad and dark green leaf varieties are preferred by farmers and consumers in Tanzania. Dinssa et al. (2018) reported a positive correlation between leaf yield and each of leaf width and leaf length, whereas in the current study, yield was correlated with leaf width but not with leaf length. The study by Dinssa et al. (2018) measured yield of leaves and petioles, whereas in the current study young stems and branches were harvested by topping the upper onethird of the plant height. The positive correlations between vegetable yield and branch number per plant in the wet-cool season trials agree with results reported by Dinssa et al. (2018). Tejaswini et al. (2017) reported positive correlation between vegetable yield and each of leaf width, leaf length, and plant height, and negative 
correlation between vegetable yield and number of branches.

Broader leaves are expected to improve light interception, resulting in increased photosynthate production. There is a strong correlation between radiation absorbed and dry matter production in crop plants (Lawlor, 1995). Leaf defoliation decreases photosynthetically active surface areas of crops leading to lower solar radiation interception and assimilate production (Ahmadi and Joudi, 2007; Lauer et al., 2004). Leaf width could serve as an important selection trait in early breeding nurseries, as its measurement is easy and straightforward, and significant positive correlations were detected between yield and leaf width at two wet-cool season trials and in all hotdry season trials, which agrees with the previous study by Dinssa et al. (2018). It was reported that indirect selection for leaf size could be used to increase foliage yield in vegetable amaranth (Shukla et al., 2005). Expected genetic advance was reported high for leaf size and vegetative yield in a study conducted in India (Shukla et al., 2006). Leaf area was reported as an important selection parameter for amaranth grain yield improvement (Kumar and Yassin, 2012). Water loss through evapotranspiration is expected to be a problem for broad-leaved varieties grown under high temperatures and low soil moisture conditions. However, the wide adoption of the broad leaf varieties of $A$. dubius by farmers in the coastal areas of Tanzania, especially in Zanzibar (island), indicates the presence of other traits for adaptation to lowmoisture and high-heat conditions. Root length measured in the hot-dry season trials was positively correlated with vegetable yield at three locations (Chambezi, Moshi, and Horti-Tengeru). Larger roots may have aided faster plant vegetative recovery after the periodic harvests. High-yielding entries at each location tended to have longer roots than low-yielding entries. Ghosh et al. (2017) reported positive correlation of root length with each of shoot weight, number of leaves per plant, and plant height in A. tricolor.

\section{Conclusion}

A diverse set of amaranth germplasms (accessions, lines, and varieties) were assessed for their adaptation across diverse growing locations and seasons, and to investigate whether different selection sites are required for various target amaranth production environments. The study revealed significant differences among the entries in vegetable yield and pointed out strong season and location effects. Entries with larger leaf width tended to give higher vegetable yield than those with narrower leaves, as observed from the positive correlation of vegetable yield with leaf width. With the exception of one, all the location mean yields were higher in the hot-dry season trials than in the wet-cool season trials. Variation among the entries was greater in the hot-dry season vs. the wet-cool season trials, indicating that entries expressed their genetic potential in the hot-dry season more than in the wet-cool season. Depending on resource availability, amaranth breeding programs may consider developing varieties targeted to a particular season (wet-cool or hot-dry season) or identify a pool of varieties well-adapted to one season, such as the hot-dry season, and test them for performance in the other season.

This study suggested two MEs not only based on performances of entries but also on similarities and differences among the locations in soil physical and chemical characteristics, weather conditions, and altitudes. None of the ME2 locations shared any of their four best entries with Chambezi location (MEl) and vice versa. This indicates that the best selections in one ME are not necessarily the best in the other ME. Each ME, therefore, may serve as the initial germplasm selection or screening site for its respective target environment in Tanzania and other countries with similar growing conditions.

\section{Literature cited}

Ahmadi, A. and M. Joudi. 2007. Effects of timing and defoliation intensity on growth, yield and gas exchange rate of the wheat grown under well-watered and drought conditions. Pak. J. Biol. Sci. 10:3794-3800

Bonasora, M.G., L. Poggio, and E.J. Greizerstein. 2013. Cytogenetic studies in four cultivated Amaranthus (Amaranthaceae) species. Comp. Cytogenet. 7:53-61.
Caselato-Sousa, M.V. and J. Amaya-Farf'an. 2012. State of knowledge on amaranth grain: A comprehensive review. J. Food Sci. 77:93-104.

Chelang'a, P.K., G.A. Obare, and S.C. Kimenju. 2013. Analysis of urban consumers' willingness to pay a premium for African leafy vegetables (ALVs) in Kenya: A case of Eldoret Town. Food Secur. 5:591-595.

Das, S. 2016. Amaranthus: A promising crop of future. Springer, Singapore.

Dinssa, F.F., P. Hanson, T. Dubois, A. Tenkouano, T. Stoilova, J. d'A. Hughes, and J.D.H. Keatinge. 2016. AVRDC The World Vegetable Center's womenoriented improvement and development strategy for traditional African vegetables in sub-Saharan Africa. Eur. J. Hort. Sci. 81:91-105.

Dinssa, F.F., R.-Y. Yang, D.R. Ledesma, O. Mbwambo, and P. Hanson. 2018. Effect of leaf harvest on grain yield and nutrient content of diverse amaranth entries. Scientia Hort. 236:146-157.

Ebert, A.W., T.-H. Wu, and S.-T. Wang. 2011. Vegetable amaranth (Amaranthus L.). p. 9. AVRDC publication number 11-754. AVRDC - The World Vegetable Center, Shanhua, Taiwan.

Environment Division. 2007. National Adaptation Programme of Action (NAPA) of Tanzania. Environ. Div., Minister of State, Vice President's Office, Dar es Salaam, Tanzania.

Escobedo-Lopez, D., C.A. Nunez-Colin, and E. Espitia-Rangel. 2014. Adaptation of cultivated amaranth (Amaranthus spp.) and their wild relatives in Mexico. J. Crop Improv. 28:203-213.

Ghosh, A., Md. Tahjib-Ul-Arif, S.G. Chamely, M.R. Haque, Md. M. Rahman, and Md. H.B. Asadul. 2017. Comparative effect of arbuscular mycorrhiza, cowdung and phosphorus on growth and yield contributing characters of red amaranth (Amaranthus tricolor L.) and indian spinach (Basella alba L.). Trop. Plant Res. 4:254-263.

Grubben, G.J.H. 2004a. Amaranthus cruentus L., p. 67-72. In: G.J.H. Grubben and O.A. Denton (eds.). Plant resources of tropical Africa (PROTA) 2. Vegetables. Backhuys, Wageningen, The Netherlands.

Grubben, G.J.H. 2004b. Amaranthus dubius Mart. ex Thell., p. 72-76. In: G.J.H. Grubben and O.A. Denton (eds.). Plant resources of tropical Africa (PROTA) 2. Vegetables. Backhuys, Wageningen, The Netherlands.

Grubben, G.J.H. 2004c. Amaranthus tricolor L., p. 84-88. In: G.J.H. Grubben 
and O.A. Denton (eds.). Plant resources of tropical Africa (PROTA) 2. Vegetables. Backhuys, Wageningen, The Netherlands.

Grubben, G.J.H. 2004d. Amaranthus blitum L., p. 63-67. In: G.J.H. Grubben and O.A. Denton (eds.). Plant resources of tropical Africa (PROTA) 2. Vegetables. Backhuys, Wageningen, The Netherlands.

Grubben, G.J.H. 2004e. Amaranthus thunbergii L., p. 63-67. In: G.J.H. Grubben and O.A. Denton (eds.). Plant resources of tropical Africa (PROTA) 2. Vegetables. Backhuys, Wageningen, The Netherlands.

Jansen, P.C.M. 2004a. Amaranthus bypochondriacus L., p. 78-80. In: G.J.H. Grubben and O.A. Denton (eds.). Plant resources of tropical Africa (PROTA) 2. Vegetables. Backhuys, Wageningen, The Netherlands.

Jansen, P.C.M. 2004b. Amaranthus spinosus L., p. 80-83. In: G.J.H. Grubben and O.A. Denton (eds.). Plant resources of tropical Africa (PROTA) 2. Vegetables. Backhuys, Wageningen, The Netherlands.

Jansen, P.C.M. 2004c. Amaranthus viridis L., p. 88-89. In: G.J.H. Grubben and O.A. Denton (eds.). Plant resources of tropical Africa (PROTA) 2. Vegetables. Backhuys, Wageningen, The Netherlands.

Kamga, R.T., C. Kouame, A.R. Atangana, T. Chagomoka, and R. Ndango. 2013. Nutritional evaluation of five African indigenous vegetables. J. Hort. Res. 21:99106.

Kumar, S.R. and G.H. Yassin. 2012. G X $\mathrm{E}$ interaction for grain yield and its contributing traits in grain Amaranthus. Intl. J. Agr. Sci. 2:265-272.
Lauer, J.G., G.W. Roth, and M.G. Bertram. 2004. Impact of defoliation on corn forage yield. Agron. J. 96:1459-1463.

Lawlor, D.W. 1995. Photosynthesis, productivity and environment. J. Expt. Bot. 46:1449-1461.

Maundu, P.M. and G.J.H. Grubben. 2004. Amaranthus graecizans L., p. 7678. In: G.J.H. Grubben and O.A. Dento (eds.) Plant resources of tropical Africa (PROTA) 2. Vegetables. Backhuys, Wageningen, The Netherlands.

Mburu, M.W., N.K. Gikonyo, G.M. Kenji, and A.M. Mwasaru. 2012. Nutritional and functional properties of a complementary food based on Kenyan amaranth grain (Amaranthus cruentus). Afr. J. Food Agr. Nutr. Dev. 12:5959-5977.

Rajaram, S., M. van Ginkel, and R.A. Fische. 1994. CIMMYT's wheat breeding mega-environments $(\mathrm{ME})$. In: Proc. $8^{\text {th }}$ Intl. Wheat Genet. Symp. China Agr. Scintech, Beijing, China. p. 1101-1106.

Schonfeldt, H. and B. Pretorius. 2011. The nutrient content of five traditional South African dark green leafy vegetables A preliminary study. J. Food Compos. Anal. 24:1141-1146.

Shukla, S., A. Bhargava, A. Chatterjee, A. Srivastava, and S.P. Singh. 2005. Estimates of genetic variability in vegetable amaranth (A. tricolor) over different cuttings. HortScience 32:60-67.

Shukla, S., A. Bhargava, A. Chatterjee, A. Srivastava, and S.P. Singh. 2006. Genotypic variability in vegetable amaranth (Amaranthus tricolor L.) for foliage yield and its contributing traits over successive cuttings and years. Euphytica 51:103-110.

Simane, B., D.G. Tanner, A. Tarekegne, and A. Taa. 1999. Agro-ecological decision support systems for wheat improvement in Ethiopia: Climatic characterization and clustering of wheat growing regions. Afr. Crop Sci. J. 7:9-19.

Stallknecht, G.F. and J.R. SchulzSchaeffer. 1993. Amaranth rediscovered, p. 211-218. In: J. Janick and J.E. Simon (eds.) New crops. Wiley, New York, NY.

Tejaswini, N., K.R. Reddy, P. Saidaiah, and T. Ramesh. 2017. Correlation and path coefficient analysis in vegetable amaranth (Amaranthus tricolor L.) genotypes. Intl. J. Curr. Microbiol. Appl. Sci. 6:2977-2996.

Yang, R.Y., S. Fischer, P.M. Hanson, and J.D.H. Keatinge. 2013. Increasing micronutrient availability from food in subSaharan Africa with indigenous vegetables, p. 231-254. In: H.R. Juliani, J.E. Simon, and C.T. Ho (eds.). African natural plant products volume II: Discoveries and challenges in chemistry, health and nutrition. Amer. Chem. Soc., Washington DC.

Yan, W., M.S. Kang, B. Ma, S. Woods, and P.L. Cornelius. 2007. GGE biplot vs. AMMI analysis of genotype-by-environment data. Crop Sci. 47:641-653.

Yan, W. and M.S. Kang. 2002. GGE biplot analysis: A graphical tool for breeders, geneticists, and agronomists. CRC Press, Boca Raton, FL.

Yan, W. and I. Rajcan. 2002. Biplot analysis of test sites and trait relations of soybean in Ontario. Crop Sci. 42:11-20.

Yan, W. and N.A. Tinker. 2006. Biplot analysis of multilocation trial data: Principles and applications. Can. J. Plant Sci. 86:623-645.

Zobel, R.W., M.J. Wright, and H.G. Gauch, Jr. 1988. Statistical analysis of a yield trial. Agron. J. 80:388-393. 